\title{
PELATIHAN DAN PEMASANGAN SAKLAR CAHAYA UNTUK FASUM DI RW. 04 DESA TALANGAGUNG KECAMATAN KEPANJEN KABUPATEN MALANG
}

\author{
M.Fahmi $\mathrm{H}^{1}$, Imron $\mathrm{R}^{2}$, Slamet $\mathrm{N}^{3}$, Hari $\mathrm{S}^{4}$, Bakti I. $\mathrm{K}^{5}$ \\ Jurusan Teknik Elektro, Program Studi Teknik Listrik, Politeknik Negeri Malang \\ e-mail: m.fahmihakim@polinema.ac.id ${ }^{1}$
}

\begin{abstract}
Abstrak - Pelatihan tentang pemasangan saklar cahaya yang benar dan sesuai standar untuk masyarakat di RW.04 Desa Talangagung Kecamatan Kepanjen Kabupaten Malang diharapkan dapat memberikan tambahan ketrampilan dalam pemasangan saklar cahaya yang benar dan standar sehingga masyarakat RW.04 bisa memasang saklar cahaya di fasum terutama dirumahnya masing masing. Kemudian masyarakat tidak perlu setiap harinya mengoperasikan ON/OFF lampu yang ada di beberapa fasum RW.04. Dengan begitu manfaat dari pemasangan saklar cahaya masyarakat tidak perlu ON/OFF lampu penerangan setiap fasum yang ada.
\end{abstract}

Kata kunci: LDR, Sel surya, saklar, instalasai

\section{PENDAHULUAN}

\subsection{Latar Belakang}

Dilingkungan masyarakat RW.04 Desa Talangagung Kecamatan Kepanjen Kabupaten Malang adalah lingkungan perumahan yang ada sejak tahun 90 an. Di lingkungan perumahan tersebut terdiri dari 4 RT dalam 1 RW yaitu RW.04. RW.04 memiliki beberapa fasum atau fasilitas umum seperti taman pintu masuk perumahan, lapangan bola voly, lapangan bulu tangkis, dan beberapa balai RT/RW serta taman di setiap RT.

Pada beberapa fasilitas umum tersebut terdapat lampu penerangan untuk penerangan pada saat warga mengunakan fasilitas tersebut. Untuk pintu masuk perumahan lampu penerangan dan lampu taman selalu dinyalakan. Pengoperasian atau ON/OFF saat ini mengunakan saklar tunggal, sehingga harus ada salah satu warga yang merelakan waktu untuk menyalakan lampu penerangan atau lampu taman setiap harinya. Warga harus menyalakan lampu setiap sore hari dan memadamkan pada pagi hari.

Pengoperasian dengan cara yang masih manual tersebut menjadi masalah ketika tidak ada salah satu warga yang peduli untuk menyalakan dan memadamkan lampu di beberapa fasum yang ada apalagi ketika cuaca sedang hujan. Sehingga terdapat beberapa lampu jalan masuk atau lampu fasum belum nyala pada saat malam hari dan terkadang pada pagi hari belum dipadamkan. Untuk itu sangat dibutuhkan saklar yang pengoperasiannya secara otomatis yaitu menggunakan saklar cahaya agar nyala dan padamya lampu bisa secara otomatis tanpa adanya warga yang mengoperasikan.

Berdasarkan kondisi lingkungan diatas maka kami melalui program Pengabdian Kepada Masyarakat (PKM) mengadakan pelatihan kepada masyarakat untuk memberikan pengetahuan tentang saklar cahaya dan memberikan pelatihan tentang cara pemasangan saklar cahaya baik dari segi teori maupun ketrampilan. Kemudian diharapkan masyarakat dapat berupaya untuk melakukan pemasangan saklar cahaya secara mandiri dirumah masing -masing.

\subsection{Tujuan Kegiatan}

1. Saklar untuk menghidupkan lampu di fasum RW.04 masih dalam kondisi pengoperasian manual.

2. Kurangnya pengetahuan tentang saklar cahaya dan ketrampilan tentang pemasangan saklar cahaya.

\section{TINJAUAN PUSTAKA}

\subsection{Macam - macam Saklar Cahaya}

2.1.1. LDR (Light Dependent Resistor)

LDR pada dasarnya merupakan suatu resisitor/tahanan yang memiliki nilai resistensi/hambatan bergantung pada intensitas/banyak-sedikitnya cahaya yang jatuh dipermukaan sensor tersebut. Cara kerja LDR adalah pada malam hari karena tidak terkena cahaya menyebabkan hambatannya membesar, sebaliknya hambatannya menjadi kecil ketika terkena cahaya pada siang hari. LDR pada umumnya berkombinasi dengan sejumlah transistor hingga membentuk rangkaian saklar lampu otomatis. Sangatlah beruntung bagi kita karena untuk membaca nilai dari hambatan pada LDR ini tidak memiliki batas khusus terhadap intesitas cahaya. Namun, hal ini yang menjadi kekurangan dari LDR, karena tidak ada batas intensitas cahayanya (trang/gelapnya) maka lampu yang diuji cobakan akan menjadi kelap-kelip / flicker.
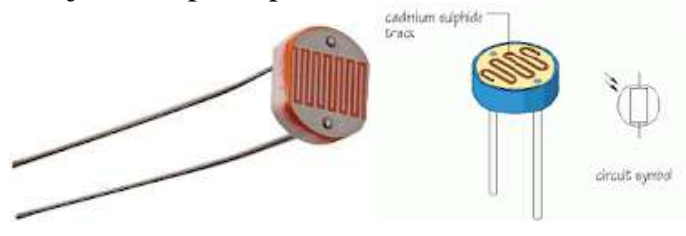

Gambar 2.1. Sensor LDR

\subsubsection{Photodiode (Dioda Foto)}

Photodiade/dioda foto adalah semacam komponen dioda yang berfungsi sebagai pendeteksi cahaya. Komponen jenis ini juga punya $\mathrm{P}-\mathrm{N}$, bedanya cuma lebih dibuat untuk sensitif terhadap cahaya. Dioda foto ini dipengaruhi jenis-jenis cahaya tertentu misalnya sinar $\mathrm{x}$, cahaya matahari, infra-red, bahkan ultra violet. Fungsi dari dioda ini juga juga bermacam-macam. Contohnya bisa kita gunakan untuk mengatur cahaya suatu kamera digital, sensor pada alat-alat medis, bisa juga untuk menghitung secara otomatis jumlah kendaraan yang lewat. 


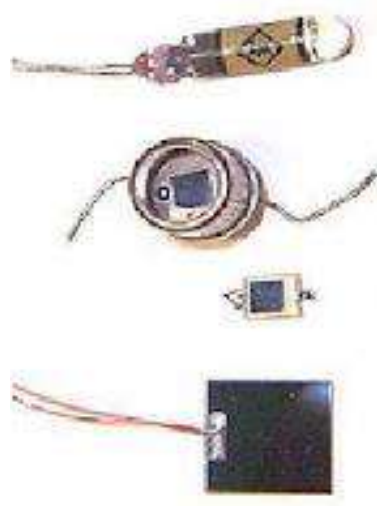

Gambar 2.2. Photodiode

\subsubsection{Photo Transistor}

Photo transistor bila kita diartikan secara sederhana yaitu komponen jenis transistor bipolar yang memakai junction / kotak base collect sebagai permukaan agar dapat menerima cahaya, dg demikian maka komponen ini mempunyai kelebihan dalam hal sensitifitas jika dibanding dgn dioda foto. Itu dikarenakan kpada photo transistor, elektronnya adalah hasil dari foton cahaya dikaki kotak yang peng-injeksiannya kebagian base transistor dan selanjutnya diperkuatn pada kolektronnya yaitu kaki C. Namun hal ini juga menimbulkan kekurangan, yaitu tanggapan terhadap cahaya menjadi lebih lambat bila dibandingkan dg dioda foto.

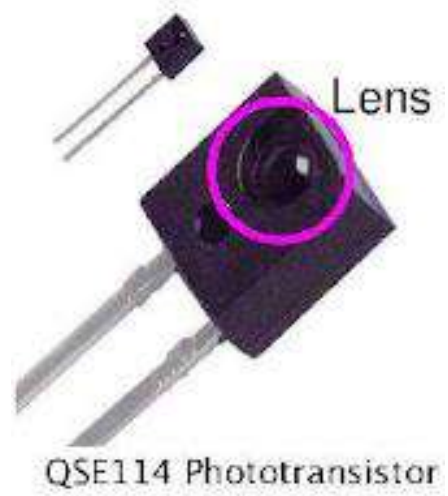

Gambar 2.3. Photo Transistor

\subsection{Pengertian Saklar atau sensor cahaya}

Sensor Cahaya (LDR) Sensor adalah alat yang digunakan untuk mendeteksi dan mengetahui magnitude tertentu. Sensor merupakan jenis transduser yang digunakan untuk mengubah variasi mekanis, magnetis,panas,sinar dan kimia menjadi tegangan dan arus listrik. Sensor memegang peranan penting dalam mengendalikan proses pabrikasi modern. (Petruzella, 2001 : 157).

Sensor yang sering digunakan dalam berbagai rangkaian elektronik salah satunya adalah sensor cahaya (LDR). Sensor cahaya adalah alat yang digunakan dalam bidang elektronika yang berfungsi untuk mengubah besaran cahaya menjadi besaran listrik. Sensor cahaya LDR (Light Dependent Resistor) merupakan suatu jenis resistor yang peka terhadap cahaya. Nilai resistansi LDR akan berubah-ubah sesuai dengan intensitas cahaya yang diterima. Jika LDR tidak terkena cahaya maka nilai tahanan akan menjadi besar (sekitar 10M $\Omega$ ) dan jika terkena cahaya nilai tahanan akan menjadi kecil (sekitar $1 \mathrm{k} \Omega$ ). (Novianty,Lubis,\& Tony, $2012: 1$ ).

Cara kerja dari sensor ini adalah mengubah energi dari foton menjadi elektron, umumnya satu foton dapat membangkitkan satu elektron. Sensor ini mempunyai kegunaan yang sangat luas salah satu yaitu sebagai pendeteksi cahaya pada tirai otomatis. Beberapa komponen yang biasanya digunakan dalam rangkaian sensor cahaya adalah LDR (Light Dependent Resistor).

Sensor cahaya yang biasanya disebut Light Dependent Resistor atau LDR. Sensor cahaya ini juga memiliki beberapa nama lain seperti foto-resistor, foto-sel, sel foto-konduktif, atau foto-konduktor. Sensor ini merupakan sebuah resistor, dimana resistor ini memiliki besaran resistansi yang dipengaruhi oleh Intensistas cahaya yang masuk menyelimuti permukaannya. Sehingga memungkinkan untuk mengaplikasikannya kedalam saklar untuk menjadi otomatis.

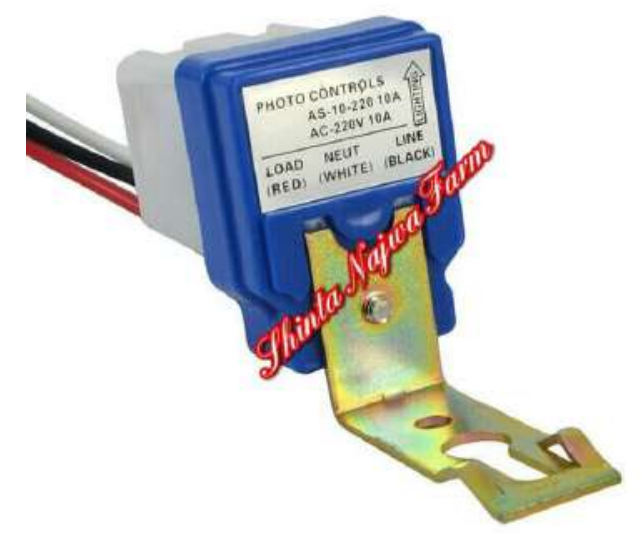

Gambar 2.4 Saklar cahaya yang banyak di pasaran

LDR ini sendiri memiliki arus listrik yang dipengaruhi melalui sinar elektromagnet. Dengan kata lain bila ditelisik lebih jauh, prinsip atau cara kerja dari resistor ini adalah dengan emisi foto-elektron atau mudahnya kerap disebut foto listrik. Cara kerjanya pun cukup sederhana. Elektron dari permukaan resistor ini akan terlepas apabila permukaan dari alat tersebut terkena sinar matahari. Sejatinya, resistor ini kerap dipakai untuk melakukan pengukuran kekuatan suatu cahaya pada sebuah kamera atau untuk mengeluarkan suaraa dari proyektor film. Tak hanya sampai disitu, LDR atau resistor ini juga sering digunakan pada solar battery, atau baterai matahari dimana pengaplikasiannya terdapat pada jam tangan ataupun kalkulator dan berfungsi untuk menampung energi dari kumpulan cahaya yang menyinarinya.

\subsection{Skema Rangkaian}

Kedua rangkaian berikut memiliki fungsi yang sama meskipun ada sedikit perbedaan antara rangkaian 1 dan 2. Perbedaan yang utama adalah pada rangkaian 2 memiliki kestabilan yang lebih bagus dibandingkan 
rangkaian 1. Hal ini karena penambahan diode 1N4007 yang berfungsi memperbaiki bentuk gelombang yang dihasilkan oleh SCR. Selain itu penambahan resistor yang dipasang parallel pada LDR membuat rangkaian menjadi lebih peka dalam merespon perubahan intensitas cahaya yang mengenai LDR.

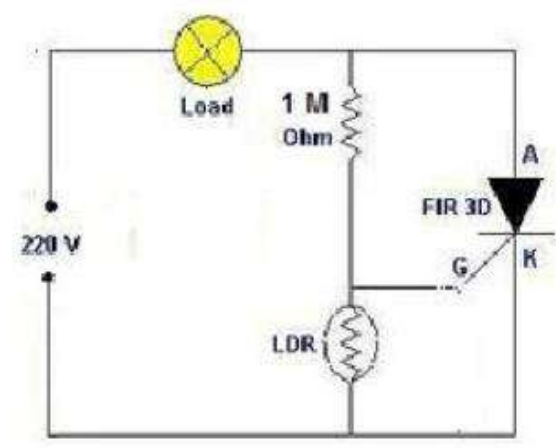

Gambar 2.5. Skema Rangkaian

\subsection{Instalasi Saklar Cahaya}

Sekarang sampailah kita kepada cara instalasinya kedalam saklar lampu. Untuk pemasangan atau instalasinya sendiri sebenarnya cukup sederhana. Karena pada dasarnya hanya ada 3 kabel yang terdapat pada resistor ini, yakni kabel merah yang berfungsi sebagai Load, kemudian ada kabel putih sebagai common atau netral, dan yang terakhir adalah kabel berwarna hitam yang digunakan sebagai Line.

Untuk lebih jelasnya bisa dilihat pada gambar berikut ini:.

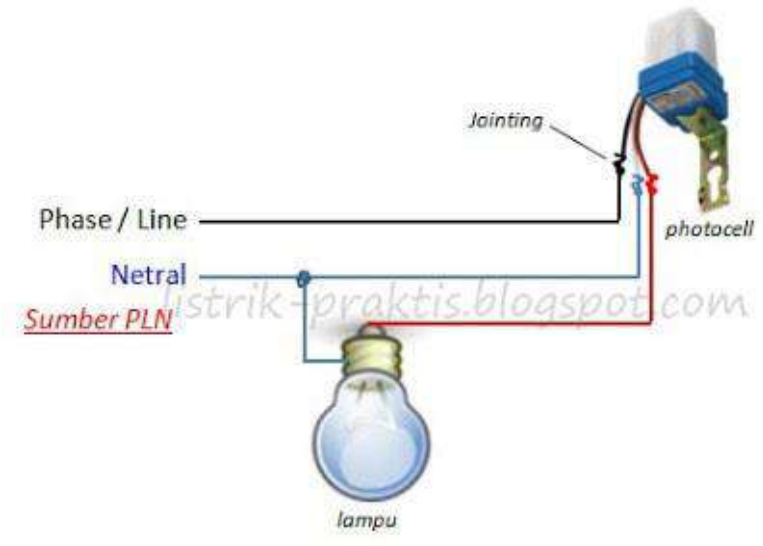

Gambar 2.6. Instalasi saklar cahaya

Keterangan gambar :

- Pada gambar Arus Listrik PLN sebesar 220 Volt (AC-220 V) terdapat dua buah kabel yakni kabel positif (+) serta Negatif (-).

- Kemudian, kabel positif (+) tadi dihubungkan ke kabel berwarna hitam dari resistor LDR yang berfungsi sebagai Line

- Selanjutnya, kabel Negatif (-) kembali dihubungkan dengan kabel berwarna putih dari resistor LDR yang berfungsi sebagai Netral.

- Dan yang terakhir kabel resistor LDR atau Foto-sel berwarna Putih dan Merah yang berfungsi sebagai common dan Load dihubungkan ke lampu

\subsection{Dasar Perancangan Instalasi Listrik}

Fasilitas komunikasi dan transportasi dunia mengalami kemajuan pesat selama beberapa dasa warsa belakangna ini, termasuk perdagangan. Untuk memudahkan perdagangan ini, standarisasi internasional disegala bidang memegang peranan yang sangat penting,namun untuk itu dibutuhkan kegiatan kerjayang sangat berat. Beberapa komisi nasional bekerja sama dengan komisi-komisi internasional.tergabung dalam suatu staff yang besar, bekerja keras mencapai kemajuan yang diharapkan.

Dalam pelajaran "Gambar Teknik" kita mengikuti standar I.S.O : International Organization Comission Cabang dari I.S.O adalah I.E.C., yakni: International Electrothecnial Comission. I.E.C. meliputi semua standarisasi peralatan listrik, seperti cara penggambaran dan kode -kode pengaman dalam pemasangannya.dalam tingkatan internasional ,I.E.C. menyusun nsemua rekomendasi dalam bentuk buku, dan komisi-komisi nasional dari semua negara anggota bertanggung jawab atas pelaksanaannya. Karena indonesia adalah negara anggota I.E.C. maka menjadi tanggung jawab kita semua untk menggunakan dan menyesuaikan semua rekomendasi I.E.C. tersebut.

Catatan :

Nomor-nomor untuk semua gambar,latihan -latihan dan sebagainya. Selalu dimulai kembali pada setiap bab atau bagian dari tersebut.

\section{MATERI DAN METODE}

\subsection{Khalayak Sasaran}

Pelatihan ini ditujukan untuk fasum di masyarakat RW.04 Desa Talangagung Kecamatan Kepanjen Kabupaten Malang.

\subsection{Metode PKM}

Untuk menentukan metode PKM maka sistem pelatihan program pengabdian kepada masyarakat ini, harus diketahui modul penunjang apa yang sesuai dengan kebutuhan lingkungan dan masyarakat, guna memenuhi sasaran yang tepat. Oleh karena itu dengan pengetahuan dan keterampilan pemasangan saklar cahaya harus sesui standar yang ada.

Dengan dibuatkan pelatihan teori saklar cahaya dan praktek pemasangan saklar cahaya di beberapa fasum RW.04 sangat cocok untuk dapat mempermudah pengoperasian lampu penerangan gapura dan taman dari manual menjadi otomatis. Dijaman ini bukan lagi barang yang baru melainkan sesuatu yang harus terpenuhi demi kemajuan dan pemenuhan kebutuhan masyarakat mengenai pengoperasian lampu penerangan dan taman tersebut.

Kegiatan pelatihan pemasangan saklar cahaya ini dilaksanakan dengan metode teori dan langsung praktek, yaitu:

1. Pengenalan peralatan dan teori standar instalasi listrik sesuai PUIL 2000.

2. Pengenalan peralatan komponen - komponen tentang saklar cahaya. 
3. Pemasangan saklar cahaya di beberapa fasum yang ada.

Metode ini dipilih karena mengingat keterbatasan waktu, tenaga, dan dana yang tersedia.

\section{PEMBaHASAN}

Hasil dari pelatihan dan pemasangan saklar cahaya adalah untuk mengurangi atau mempermudah operator yakni manusia dalam melakukan pengoperasian menyalakan dan memadamkan lampu pada fasum di RW. 04. Banyak dari warga yang ingin memasang saklar cahaya dirumahnya untuk mempermudah menyalakan dan memadamkan lampu di bagian teras, selain itu yang paling penting ketika mereka bepergian saat pulang kampung sampai beberapa hari lampu teras rumah tidak menyala secara terus menerus yakni dapat ON dan OFF secara otomatis. Warga menyadari bahwa begitu penting saat rumah mereka kosong dalam beberapa hari sehingga banyak dari warga yang akan memasang saklar cahaya di rumah.

Kemudian dikarenakan warga yang rata - rata adalah orang awam maka perlu juga ditekankan pada saat instalasi ketika memasang saklar cahaya terutama perlu diketahui bahwa hubungan arus pendek atau korsleting adalah kontak langsung antara kabel positif dan negatif yang biasanya dibarengi dengan percikan bunga api, dan bunga api inilah yang memicu kebakaran.

Sebelum mengganti saklar tunggal menjadi saklar cahaya yang otomatis maka kita perlu mengetahui konsep bagaimana instalasi saklar tinggal bisa menyalakan atau memadamkan lampu. Rangkaianrangkaian penerangan dengan hanya satu saklar dinamakan sistem pengaturan peneranga satu arah. Walaupun dalam rangkaian-rangkaian penerangan tersebut, dipasang beberapa buah lampu penerangan yang berbeda, tetapi hanya diatur oleh satu saklar, maka sistem rangkaian yang demikianpun disebut pengaturan satu arah.

Ditunjukan suatu rangkaian pengaturan penerangan satu arah. Gambar 4.1 tersebut memperlihatkan suatu lokasi (penempatan) peralatan dengan menggunakan simbol-simbol yang sesuai. Penggambaran yang demikian disebut sebagai diagram lokasi.

Sistem Pengaturan Penerangan Satu Arah :

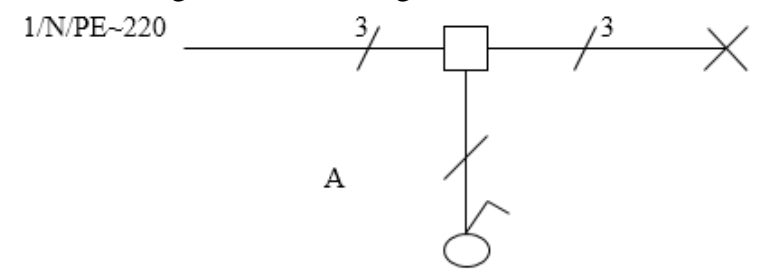

Gambar 4.1. Diagram lokasi

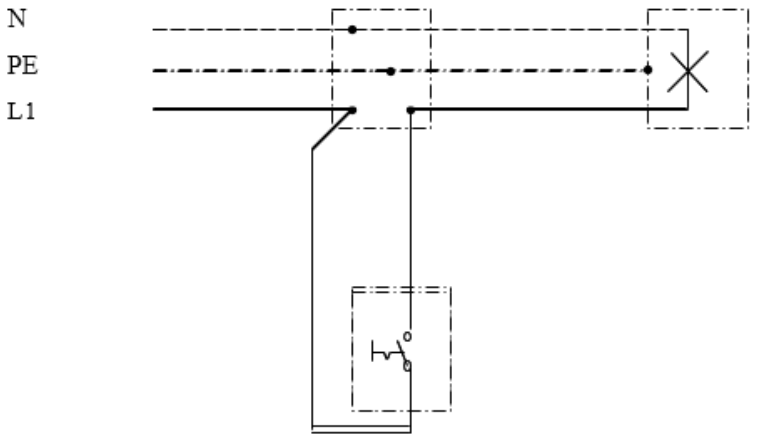

Gambar 4.2. Diagram pengawatan Dengan garis jamak

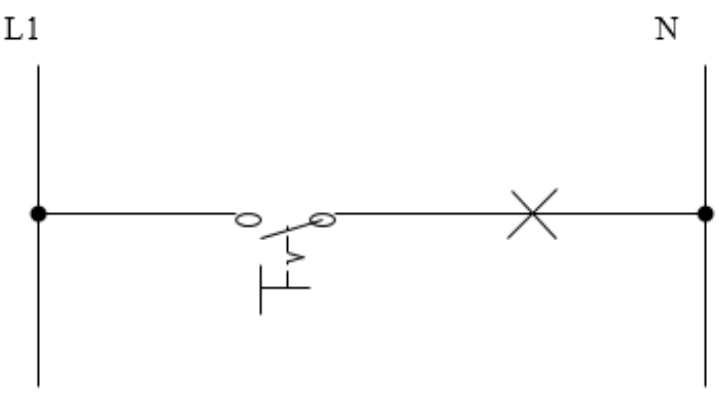

Gambar 4.3. Diagram kerja Dengan satu garis

Keterangan :

1. Pada sistem TN, hanya penghantar aktif (line 1, 2, 3) yang bertegangan, sedangkan penghantar pentanahan (N, PE dan PEN) tidak bertegangan. (hal ini akan dibahas lebih lanjut dalam pelajaran "Electrodynamics"). Berdasrka ketentuan diatas, maka saklar harus selalu dikawati dengan penghantar aktif. Mengapa?

Jika saklar dikawati dengan penghantar pentanahan, maka alat pemakai (beban) dan pentanahannya akan selalu bertegangan, walaupun saklar dalam posisi off, keadaan yang demikian akan berbahaya sekali bagi kita contohnya jika kita akan mengganti lampu.

2. Titik terminal untuk penghantar aktif pada saklarsaklar biasanya ditandai dengan huruf $\mathrm{P}$ atau $\mathrm{L}$ dengan bulatan merah.

Penandaan ini penting sekali untuk saklarsaklaryang mempunyai lebih dari dua titik terminal.

3. Untuk menghindari kekeliruan dan kesalahan pengoperasian. Maka pengertian untuk pengoperasian suatu saklar pengatur adalah di tentukan sebagai berikut:

Kita ambil contoh, suatu saklar satu arah pada "posisi - on":

\begin{tabular}{|l|l|}
\hline Arah pengoperasian & $\begin{array}{l}\text { Pengertian } \\
\text { pengoperasian }\end{array}$ \\
\hline Tegak & Keatas \\
\hline Tegak kedalam & Keluar \\
\hline Mendatar & Kekanan \\
\hline
\end{tabular}

4. Penghantar aktif setelah melalui saklar disebut penghantar saklar

5. Perhatikan pada suatu pegangan bola lampu. Disitu terdapat titik terminal untuk kaki - kontak dan yang laen untuk ulur pemegang lampu. Pada suatu 
pegangan lampu dengan perangkat yang terbuat dari metal biasanya mempunyai terminal tambahan untuk penghantar pentanahan Dimanakah akan anda hubungkan penghantar tersebut? Jawab:

Alasan: penghantar pentanahan (PE) harus dipasang, karena pegangan lampu mudah sekali tersentuh.

Berikut adalah langkah - langkah melakukan pengantian saklar tunggal menjadi saklar cahaya :

1. Matikan atau OFF kan sumber tegangan yaitu melalui MCB.

2. Lepaskan saklar tunggal untuk lampu yang akan di operasikan otomatis menggunakan saklar cahaya.

3. Setelah kabel menuju saklar dilepas sambungkan dengan kabel warna hitam di saklar cahaya. Tambahkan kabel menuju ke luar rumah yang saklar cahayanya terkena sinar matahari.

4. Keluaran dari saklar cahaya yang warna merah sambungkan ke kabel fasa lampu (bisa dari output saklar tunggal).

5. Sambungkan netral dengan kabel warna putih yang ada di saklar cahaya.

Lebih jelasnya bisa dilihat pada gambar 2.6. instalasi saklar cahaya pada bab II.

Apabila mungkin ada yang belum yakin bisa melakukan pengantian saklar tunggal menjadi saklar cahaya sebaiknya menyerahkan kepada ahlinya yang sudah berpengalaman pada bidang instalasi listrik dikarenakan kesalahan penyambungan kabel atau instalasi dapat menyebabkan bahaya dan terjadi kebakaran, ada beberapa cara untuk mencegah terjadinya kebakaran sebagai berikut :

1. Sebaiknya serahkan pemasangan instalasi rumah/bangunan anda pada instalatir yang terdaftar sebagai anggota AKLI (Assosiasi Kontraktor Listrik Indonesia) dan terdaftar di PLN. Secara legal instalatir mempunyai tanggung jawab terhadap keamanan instalasi.

2. Usahakan untuk menghindari menumpuk steker atau colokan listrik terlalu banyak pada satu tempat (stopkontak) karena sambungan seperti itu akan terus menerus menumpuk panas yang akhirnya dapat mengakibatkan korsleting listrik.

3. Gunakanlah peralatan listrik yang memenuhi standar SNI dan_ukuran yang tepat.

4. Gunakanlah sekring yang masih bagus dan gantilah sekring putus dengan yang baru, jangan mencoba untuk menyambung sekring dengan kawat serabut.

5. Rawatlah instalasi listrik secara berkala untuk mengetahui bila terjadi kerusakan pada kabel atau peralatan listrik misalnya isolasi yang terbuka pada sambungan. bila memungkinkan gantilah seluruh jalur instalasi setiap lima tahun sekali.

6. Gunakan jenis dan ukuran kabel sesuai peruntukan dan kapasitas hantar arusnya.

7. Bila terjadi kebakaran akibat korsleting listrik pengaman Mini Circuit Breaker (MCB) tidak berfungsi dengan baik, matikan segera listrik dari KWH meter. Jangan menyiram sumber kebakaran dengan air bila masih ada arus listrik.
8. Bila membutuhkan sambungan listrik baru daftarlah secara legal ke PLN, jangan menyantol dari sumber yang illegal.

\section{KESIMPULAN DAN SARAN}

\subsection{Kesimpulan}

Setelah kami melakukan pelatihan dan pemasangan saklar cahaya untuk fasum RW.04 Desa Talangagung Kec. Kepanjen Kab. Malang, maka dapat diambil kesimpulan sebagai berikut :

1. Pelatihan dan pemasangan saklar cahaya sangat membantu warga dalam mengoperasikan lampu yang ada di fasum. Hasil dari pemasangan saklar cahaya di wasum warga tidak perlu repot - repot untuk menyalakan lampu dan memadamkan lampu yang ada di fasum.

2. Hasil dari pelatihan pemasangan adalah warga mengetahui bagaimana cara menganti saklar tunggal menjadi saklar cahaya yang otomatis, bahkan warga ingin memasang saklar cahaya dirumahnya sehingga ketika rumah tidak ada orang lampu teras tetap bisa menyala dan padam secara otomatis.

\subsection{Saran}

Perlu adanya tindak lanjut dari kegiatan ini, terutama dalam memberikan pelatihan dan penyuluhan terkait instalasi listrik dirumah tangga

\section{DAFTAR PUSTAKA}

[1]. Jatmiko Tutuk. Teknik Instalasi Pemanfaatan Tenaga Listrik. SMK Ibrahimy Panji, Situbondo.

[2]. Badan Standarisasi Nasional. 2000. Persyaratan Umum Instalasi Listrik 2000 (PUIL2000). Jakarta.

[3]. Harten, P.Van, \& E.Setiawan. 1978. Instalasi Listrik Arus Kuat 1. Nedherland.

[4]. Harten, P.Van, \& E.Setiawan. 1978. Instalasi Listrik Arus Kuat 2. Nedherland.

[5]. Heri S., \& Ruwah J.. 2012. Job Sheet Bengkel Listrik II. Politknik Negeri Malang.

[6]. PEDC. 1984. Electrical Design. Bandung 